\title{
The Outcome of Combined Electro-fulguration and Surgical Excision Techniques in the Management of Anogenital Condylomas
}

\section{Anogenital Kondilom Tedavisinde Elektro-fulgurasyon ve Cerrahi Eksizyon Tekniklerinin Birlikte Kullanımının Sonuçları}

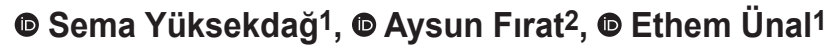 \\ 1 University of Health Sciences, Ümraniye Training and Research Hospital, Clinic of General Surgery, İstanbul, Turkey \\ 2University of Health Sciences, İstanbul Training and Research Hospital, Clinic of Obstetrics and Gynecology, İstanbul, Turkey
}

\section{IIIIIIII| ABSTRACT}

Aim: Condyloma accuminata (anogenital warts) refers to an epidermal manifestation attributed to human papilloma virus (HPV). It is the most common sexually transmitted disease. In this study, we present our experience with anogenital warts and surgical treatment outcomes.

Method: From 2013 to 2018, 53 patients with anogenital warts underwent electro-fulguration (cauterization) and surgical excision under local or general anesthesia. Demographics, localization of lesions, serological tests, final histopathological results, outcomes and recurrence rates were documented.

Results: There were 37 men (69.8\%) and 16 women (30.1\%). The mean age was 37 years (range= 17-53). Local or general anesthesia was applied according to the localization, distribution and volume of the lesions ( $\mathrm{n}=46,86.7 \% \mathrm{vs} . \mathrm{n}=7,13.2 \%$, respectively). Surgical excision was performed for histopathological examination, and electro-fulguration was applied for multiple smaller lesions. The perianal region was the most common location for HPV-related warts ( $n=24,64.8 \%$ for men vs. $n=14,87.5 \%$ for women). Human immunodeficiency virus (HIV) positivity was seen in three patients (5.6\%). Hepatitis serology was positive in two cases (3.7\%). There was no permanent surgical morbidity. During a mean follow-up period of 31 months (range: 5-61 months), recurrence was seen in five cases (9.4\%), and two of them were HIV positive (40\% of recurrent cases).

Conclusion: HPV-related anogenital warts remain one of the most common sexually transmitted diseases. Surgical excision to confirm diagnosis and fulguration of the remaining lesions can be recommended in practice. HIV positivity and high recurrence rates are the most important problems to be encountered.

Keywords: Anogenital condyloma, warts, human papilloma virus, surgical excision, electro-fulguration, cauterization

\section{|H॥IIII| ÖZ}

Amaç: Kondiloma akümünata (anogenital siğiller), insan papilloma virüsünün (HPV) yol açtı̆̆ı epidermal lezyonların adıdır. En sık rastlanan cinsel yolla bulaşan hastalığı oluşturmaktadır. Bu çalışmada, anogenital bölge siğilleri ve cerrahi tedavinin sonuçlarına dayanan deneyimimizi aktarmayı hedefledik.

Yöntem: 2013-2018 arası dönemde, anogenital kondilom nedeniyle toplam 53 hastaya lokal veya genel anestezi altında elektro-fulgurasyon (koterizasyon) ve cerrahi eksizyon işlemi yapıldı. Demografik bilgiler, lezyonların lokalizasyonu, serolojik test sonuçları, histopatolojik tanı ile elde edilen sonuçlar ve nüks oranları değerlendirildi.

Bulgular: Hastaların 37'si erkek (\%69,8), 16’sı kadın (\%30,1) idi. Yaş ortalaması 37 yıl (17-53 arasında) olarak hesaplandı. Lezyonların lokalizasyonu, dağılımı ve büyüklüğü dikkate alınarak lokal veya genel anestezi uygulandı (sırasıyla, n=46, \%86,7 ve n=7, \%13,2). Tüm hastalara histopatolojik örnekleme amaçlı cerrahi eksizyon ve diğer daha küçük lezyonlar için elektro-koterizasyon uygulandı. HPV’ye bağlı lezyonların en çok perianal bölgeye yerleştiği tespit edildi ( $\mathrm{n}=24, \% 64,8$ erkek; $\mathrm{n}=14, \% 87,5$ kadın). Üç hastada $(\% 5,6)$ insan immün yetmezliği virüsü (HIV) pozitifliği saptandı. Hepatit serolojisi ise 2 hastada $(\% 3,7)$ pozitif idi. Kalıcı cerrahi morbidite görülmedi. Ortalama 31 aylık (5-61 ay arasında) takip süresi boyunca 5 hastada $(\% 9,4)$ nüks görülürken bu hastaların 2'si HIV pozitif idi (tüm nükslerin \%40'1).

Address for Correspondence/Yazışma Adresi: Ethem Ünal MD,

University of Health Sciences, Ümraniye Training and Research Hospital, Clinic of General Surgery, İstanbul, Turkey

E-mail: drethemunal@gmail.com ORCID ID: orcid.org/0000-0003-4056-4874

Received/Geliş Tarihi: 30.07.2019 Accepted/Kabul Tarihi: 06.08.2019

${ }^{\circledR}$ Copyright 2019 by Turkish Society of Colon and Rectal Surgery

Turkish Journal of Colorectal Disease published by Galenos Publishing House. 
Sonuç: HPV'ye bağlı gelişen anogenital siğiller, cinsel yolla bulaşan hastalıklar arasında önemli bir yer tutmaktadır. Günlük pratikte, teşhisin ispatı için cerrahi eksizyon ile kalan lezyonların fulgurasyonunun birlikte yapılması önerilebilir. HIV pozitifliği ve yüksek nüks oranları en çok karşılaşılan problemleri oluşturmaktadır.

Anahtar Kelimeler: Anogenital kondiloma, siğiller, human papilloma virüs, cerrahi eksizyon, elektro-fulgurasyon, koterizasyon

\section{Introduction}

Anogenital condyloma (condyloma acuminata) is a sexually transmitted disease that starts as brown small spot lesions around the genital area or anus with ability to grow and spread over time. When the lesions are small, they may not even be recognized because they do not cause pain or discomfort. Itching, hemorrhage, mucous discharge and causing a feeling of mass as it grows are the most common symptoms. The causative agent of the disease is human papilloma virus (HPV) and it is sexually transmitted by direct contact. ${ }^{1}$ Depending on the patient's immunological structure (organ transplant, immunosuppressive drug use, patients with chronic immune diseases such as inflammatory bowel disease or rheumatoid arthritis), the time of onset of symptoms varies. ${ }^{2,3}$ The disease is also frequently seen in people infected with human immunodeficiency virus (HIV). Following detailed physical examination and serological tests, there is controversy as to whether condylomas should be removed or medically treated. However, in the current literature, the necessity of coagulation or excision is suggested, considering that the untreated disease will spread and the lesions will grow. ${ }^{4,5,6}$ Knowing increased risk of anal carcinoma is another factor in this patient group. ${ }^{6}$ The efficacy of podophylline, topical pomades containing bi or tri-chloro-acetic acid and agents such as imiquimod or 5-fluorouracil (5-FU) is controversial. ${ }^{7,8}$ These drugs are known to cause irritation, burning and painful ulcers in the skin. ${ }^{8}$ Cryotherapy treatment of condylomas with liquid nitrogen can also be made. ${ }^{9}$ Its effectiveness in large and widespread lesions appears to be limited. The most commonly used surgical treatment methods are fulgurization or surgical excision of lesions under local or general anesthesia. It can be applied in combination according to the number, location and size of the lesions. ${ }^{4}$ It has advantages such as rapid results, allowing histopathological evaluation and faster return to the sexual life of the patient, as well as the disadvantages of anesthesia and surgery. In this study, we aimed to report the outcomes of patients who were diagnosed with anogenital condyloma at the general surgery outpatient clinics of our hospital and who underwent fulguration and surgical excision with electro-cautery.

\section{Materials and Methods}

The Ethics Committee approval was obtained from our hospital

(23.01.2019/B.10.1.TKH.4.34H.GP.0.01/4).
During the five-year period between December 2013 and December 2018, the files of 53 patients who were diagnosed and treated by a single surgeon in surgical outpatient clinics were evaluated. Serological tests (hepatitis B, C and HIV) were requested in all patients who were diagnosed as anogenital condyloma by physical examination. According to the localization, distribution and size of the lesions, procedures were performed under local anesthesia in the outpatient clinic conditions or under general anesthesia in the operating room following the necessary preparation. All patients were discharged on the same day with a prescription containing prophylactic antibiotics (oral and externally on the skin) and painkillers. After the consent form was signed for all patients, the technique applied was the same: surgical excision using thin-tipped tissue scissors for histopathological diagnosis and electro-cautery fulguration of smaller burnable lesions in sterile environment. Large or large-base lesions were also excised with thin-tipped tissue scissors. If the wound margins were distant after excision, 3 or $4 / 0$ prolene suture (prolene, Ethicon, USA) was used for closure. In the technique we applied, electro-cautery fulguration was done in the form of burning deep to the subcutaneous tissue, since it is known that condyloma could reach subcutaneous tissue and survive in the latent period. All patients were informed about the ways of transmission, prevention methods and the possibility of recurrence, and histopathological diagnosis was obtained. Patients were followed up by the same surgeon under the conditions of the outpatient clinic. All patients were informed about the general characteristics of the disease and virus, and the ways of protection were explained and all patients with positive serology were referred to the infectious diseases outpatient clinics. Demographic data, localization of lesions, serological test results, histopathological diagnoses, clinical course and recurrence rates were recorded.

\section{Results}

Of the 53 patients, 37 were male (69.8\%) and 16 were female $(30.1 \%)$. The mean age was 37 years (range $=17-53$ ). Most of the procedures $(n=46,86.7 \%)$ were performed under local anesthesia in outpatient clinics. General anesthesia was applied to patients with large and widespread lesions under operating room conditions $(n=7,13.2 \%)$. HPVrelated lesions were mostly located in the perianal region 
( $\mathrm{n}=24,64.8 \%$ male; $\mathrm{n}=14,87.5 \%$ female). HIV positivity was detected in three patients (5.6\%). Hepatitis serology was positive in two patients (3.7\%). Both of these patients had hepatitis B antigen.

All patients were discharged on the same day and no patient had permanent surgical morbidity (Figures 1 and 2). In the follow-up and outpatient follow-up visits, it was seen that

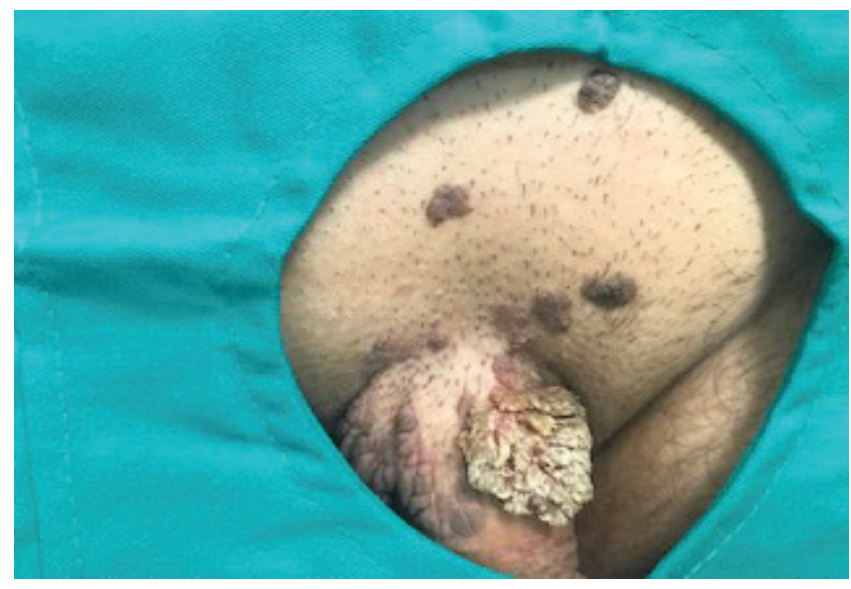

Figure 1. Human papillama virus-induced genital warts (condyloma accuminata)

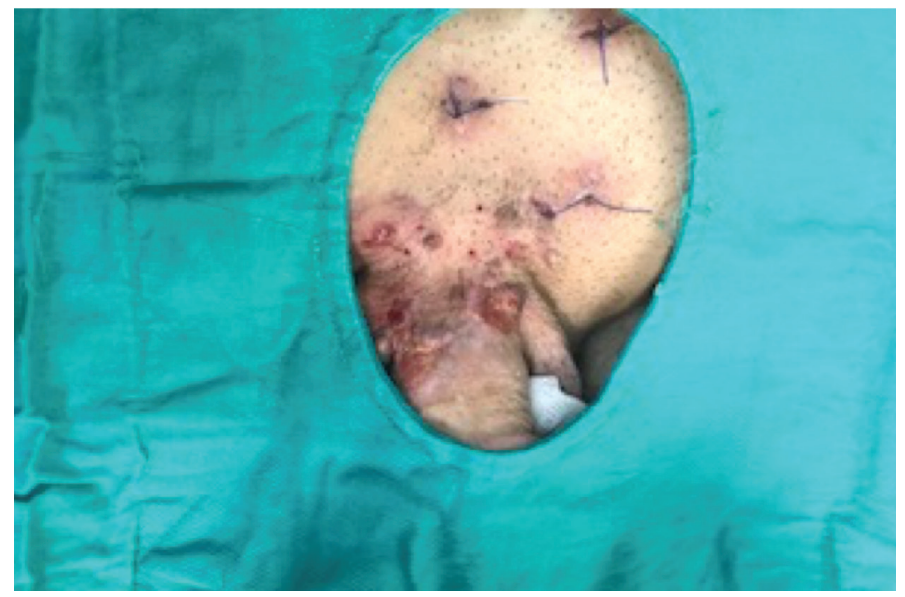

Figure 2. Early recovery period after surgical treatment (combined surgical excision and electro-fulguration) all patients had complete wound healing until the end of the first month. During the mean follow-up period of 31 months (range $=5$ to 61 months), five patients (9.4\%) developed recurrence and two of these patients were treated for HIV ( $40 \%$ of all relapses). Demographic data, distribution of lesions, serology results and recurrence rates of our patients are summarized in Table 1. Histopathologic diagnosis was consistent with HPV lesion in all patients included in the study. Patients with histopathological diagnosis of molluscum contagiosum, fibroepithelial polyp and squamous papilloma were excluded from the study. Rectosigmoidoscopy was performed in patients who developed recurrence and same procedure was applied. Rectal mucosal involvement was not observed in these patients. In all three of our patients (all males, patients with anal region involvement), HIV positivity was determined by serological tests routinely requested at the time of first admission. These patients were referred to the infectious diseases outpatient clinic and their treatments were arranged. Two patients who developed recurrence were found to be under antiretroviral therapy and to receive anti-opportunistic prophylaxis. CD4 levels of these patients were recorded as 120 and $180 \mathrm{~mm}^{3}$ despite treatment.

\section{Discussion}

Anogenital condyloma is the most common sexually transmitted disease in the United States, where 500.000 to one million new cases are added each year, and is caused by HPV, a member of the double-deoxyribonucleic acid stranded papova virus family with more than 120 subtypes. ${ }^{4,10}$ Although at least 40 types can be isolated in the anogenital region, HPV types 6 and 11, which have a high risk of contamination but low incidence of intraepitalial dysplasia, are the main factors in anogenital condylomas. ${ }^{11}$ HPV types 16 and 18, which have a high oncologic potential, can remain latent for a long time in both epidermal keratinocytes and mucosal epithelium, leading to large condylomas (BuschkeLowenstein tumor) and cervical and anus carcinomas after intraepithelial dysplasia. ${ }^{12}$ Although the incubation period for the occurrence of lesions after HPV infection has been

Table 1. Demographic data, distribution of lesions, serology results and recurrence rates of patients presenting with anogenital condyloma

\begin{tabular}{|c|c|c|c|c|c|c|}
\hline \multirow[t]{2}{*}{ Recurrence } & \multirow{2}{*}{$\begin{array}{c}\text { Number } \\
\text { (n) }\end{array}$} & \multirow{2}{*}{$\begin{array}{l}\text { Age } \\
\text { (average.) }\end{array}$} & \multicolumn{2}{|c|}{ Lesion distribution } & \multicolumn{2}{|c|}{ Serology positivity } \\
\hline & & & $\begin{array}{l}\text { Anus } \\
\text { (pubis, pen }\end{array}$ & $\begin{array}{l}\text { iital } \\
\text { gina) }\end{array}$ & HIV & HBV \\
\hline Total 5 (9.4\%) & 53 & $37(17-53)$ & $38(71.6 \%)$ & $15(28.3 \%)$ & $3(5.6 \%)$ & $2(3.7 \%)$ \\
\hline Man 4 (80\%) & $37(69.8 \%)$ & $29(17-46)$ & $24(63.1 \%)$ & $13(86.6 \%)$ & $3(100 \%)$ & $2(100 \%)$ \\
\hline Woman 1 (10\%) & $16(30.1 \%)$ & $42(19-53)$ & $14(36.8 \%)$ & $2(13.3 \%)$ & - & - \\
\hline
\end{tabular}

HIV: Human immunodeficiency virus, HBV: Hepatitis B virus 
reported between 3 weeks and 8 months, it is known to remain silent for many years in the majority of epithelial cells. ${ }^{4}$ It has been suggested that subclinical HPV infection can reach $40 \% .{ }^{13}$ However, risk factors such as polygamous sexual life, smoking, immunosuppressive diseases and HIV infection have been shown to cause earlier symptoms in patients infected with HPV. ${ }^{3}$ In some studies on HIV positive patients, HPV coinfections have been reported in $30 \%$ of this patient group during their lifetime. ${ }^{3,4}$ High risk of transmission and malignancy potential of the disease necessitates treatment. The efficacy of tetravalent vaccines developed for the high-risk population and introduced in many countries is controversial. ${ }^{14}$ The treatment methods known and practiced today are directed to the elimination of lesions rather than elimination of viral load, and are based on a number of applications in which different costs, dosages and treatment times, side effects and outcomes occur, and cannot prevent common recurrences. Podophylline (0.05-0.15\%) which inhibits mitotic division by binding to intracellular microtubules can be used as solution, cream and gel three times a week for a maximum of four weeks and causes erosion on the lesions and necrosis. ${ }^{7}$ Although the success rate of treatment is reported to be between 45 and $77 \%$, the recurrence rate of the lesions is $40 \%{ }^{4,15}$ It can cause pain, itching, erosion, burning and inflammation, and is not recommended for use in pregnant women. Bi- or trichloro-acetic acid (80-90\%) is an inexpensive chemical agent that burns and erodes the skin and mucous membranes, and is usually applied by the physician for several sessions, with a success rate of $70-80 \%$ and recurrence rates close to $40 \% .{ }^{4,16}$ Pain and burning sensation and ulceration are the most common side effects. Imiquimod (3.75-5\%) is a topical immunomodulatory agent that can be administered by the patient and is used in cream form. ${ }^{8}$ It can be used up to 16 weeks, three times a week before bedtime, and may cause itching, erythema, tenderness, ulceration and pain. The success rate is between 40 and $77 \%$, and the recurrence is low (13\%); however, local inflammatory side effects are more severe. ${ }^{4}$ 5-FU and interferon treatments are not recommended today. Cryotherapy of condylomas with liquid nitrogen can also be performed. ${ }^{16}$ However, its efficacy in larger and widespread lesions appears to be limited. In addition, painful bullae and permanent scar formation, local pigment loss and infection are common. Although it provides $79-88 \%$ elimination in the first three cycles, recurrence rates are between $25-40 \% .4,9$ Surgical procedures performed in anogenital condylomas are usually performed in outpatient clinics or operating room conditions depending on the location, number and extent of the lesions. Electrocautery technique provides thermal coagulation and fulguration of lesions by applying high frequency electric current. Local anesthesia is required. It is not recommended, as it will cause permanent scar tissue in large lesions. Long-term results are similar to cryotherapy, but are contraindicated in patients with cardiac pacemakers. ${ }^{4,17}$ Surgical excision is the only option in the treatment of large lesions that cover the urethral meatus or anus and should be performed under general anesthesia. ${ }^{4}$ Tissue scissors or scalpel can be used. It allows histopathological diagnosis especially in lesions suspected of malignancy. Besides side effects of local or general anesthesia, infection, hemorrhage, serous discharge or hematoma may be seen. Our preferred method is combined use of fulguration and surgical excision. Surgical excision of large-based or large lesions can be performed under local anesthesia, without pain, in combination with the fulguration method, which is mostly used to eliminate small lesions. In our series, only $13 \%$ of patients had to receive general anesthesia because of the size or extent of the lesions. The combined use of these two methods allowed for the rapid evacuation of small lesions by cautery and excision of larger lesions to allow histopathological identification; thus, a definitive histological diagnosis was obtained in all patients. In addition, rapid results were obtained in a single session, allowing patients to return to their sexual life faster and labor loss was minimized. In our series, no significant morbidity was observed, and the recurrence rate was also very low (close to 10\%) during the follow-up period of approximately three years. HIV positive patients accounted for $40 \%$ of the recurrence cases. In large series including all treatment modalities, the early recurrence rate of the disease (first 3 and 5 years) is generally reported to be around 30 to $50 \% .{ }^{4,10,11}$ It is important for patients to be aware of possible new lesion development early and patients should be trained to prevent HPV spread. In our practice, serological tests including hepatitis B and C as well as HIV tests are requested in all patients with anogenital condyloma, and the results are consulted to relevant specialists after surgical treatment. In our study, histopathological examination was requested in all patients, so that differential diagnosis of lesions similar to HPV warts in physical examination such as molluscum contagiosum, fibroepithelial polyp and squamous papilloma could be made.

\section{Conclusion}

In conclusion, HPV-induced anogenital warts play an important role among sexually transmitted diseases. Topical, immune and surgical treatment methods are prominent in the treatment of the disease. However, in order to eliminate all small or large lesions in a single session and to allow histopathological examination, it may be recommended to perform surgical excision and fulguration of the remaining lesions. HIV positivity and high recurrence rates continue to be the most common problems. 


\section{Acknowledgements}

We would like to express our love and gratitude to our clinic secretary Esma Mekancan and our health officer Fuat Kaya for their great efforts and efforts in the surgical procedures we performed under local anesthesia.

\section{Ethics}

Ethics Committee Approval: The Ethics Committee approval was obtained from Ümraniye Training and Research Hospital (23.01.2019/B.10.1.TKH.4.34H.GP.0.01/4).

\section{Informed Consent: Was taken.}

Peer-review: External and internal peer-reviewed.

\section{Authorship Contributions}

Surgical and Medical Practices: E.Ü., Concept: A.F., Design: S.Y., A.F., Data Collection or Processing: S.Y., Analysis or Interpretation: S.Y., A.F., E.Ü., Literature Search: A.F., Writing: S.Y., A.F., E.Ü.

Conflict of Interest: No conflict of interest was declared by the authors.

Financial Disclosure: The authors declared that this study eceived no financial support

\section{References}

1. Ong KJ, Checchi M, Burns L, Pavitt C, Postma MJ, Jit M. Systematic review and evidence synthesis of non-cervical human papillomavirus-related disease health system costs and quality of life estimates. Sex Transm Infect $2019 ; 95: 28-35$.

2. Florin HJ, Snoeck R, Van Cleynenbreugel B, Albersen M. Treatment of intraurethral condylomata acuminata with surgery and cidofovir instillations in two immunocompromised patients and review of the literature. Antiviral Res 2018;158:238-243.

3. Werner RN, Westfechtel L, Dressler C, Nast A. Anogenital warts and other HPV-associated anogenital lesions in the HIV-positive patient: a systematic review and meta-analysis of the efficacy and safety of interventions assessed in controlled clinical trials. Sex Transm Infect 2017;93:543-550.

4. Yanofsky VR, Patel RV, Goldenberg G. Genital warts: A comprehensive review. J Clin Aesthet Dermatol 2012;5:25-36.

5. De Toma G, Cavallaro G, Bitonti A, Polistena A, Onesti MG, Scuderi N. Surgical management of perianal giant condyloma acuminatum (Buschke-
Löwenstein tumor). Report of three cases. Eur Surg Res 2006;38:418-22.

6. Kobayashi T, Sigel K, Kalir T, MacLeod IJ, Liu Y, Gaisa M. Anal cancer precursor lesions in HIV-infected persons: Tissue human papillomavirus type distribution and impact on treatment response. Dis Colon Rectum 2019;62:579-585.

7. Von Krogh G. Podophyllotoxin for condylomata acuminata eradication. Clinical and experimental comparative studies on Podophyllum lignans, colchicine and 5-fluorouracil. Acta Derm Venereol Suppl (Stockh) 1981;98:1-48.

8. Edwards L, Ferenczy A, Eron L, Baker D, Owens ML, Fox TL, et al. Selfadministered topical 5\% imiquimod cream for external anogenital warts. HPV Study Group. Human PapillomaVirus. Arch Dermatol 1998;134:2530.

9. Scheinfeld N, Lehman DS. An evidence-based review of medical and surgical treatments of genital warts. Dermatol Online J 2006;12:5.

10. Cates W Jr. Estimates of the incidence and prevalence of sexually transmitted diseases in the United States. American Social Health Association Panel. Sex Transm Dis 1999;26:2-7.

11. Tyring SK. Human papillomavirus infections: epidemiology, pathogenesis, and host immune response. J Am Acad Dermatol 2000;43:18-26.

12. Schwartz RA. Verrucous carcinoma of the skin and mucosa. J Am Acad Dermatol 1995;32:1-21.

13. Baken LA, Koutsky LA, Kuypers J, Kosorok MR, Lee SK, Kiviat NB, et al. Genital human papillomavirus infection among male and female sex partners: prevalence and type-specific concordance. J Infect Dis 1995;171:429-432.

14. Garland SM, Kjaer SK, Munoz N, Block SL, Brown DR, DiNubile MJ, et al. Impact and Effectiveness of the Quadrivalent Human Papillomavirus Vaccine: A Systematic Review of 10 Years of Real-world Experience. Clin Infect Dis 2016;63:519-527.

15. Greenberg MD, Rutledge LH, Reid R, Berman NR, Precop SL, Elswick RK. A double-blind, randomized trial of $0.5 \%$ podofilox and placebo for the treatment of genital warts in women. Obstet Gynecol 1991;77:735-739.

16. Godley MJ, Bradbeer CS, Gellan M, Thin RN. Cryotherapy compared with trichloroacetic acid in treating genital warts. Genitourin Med 1987;63:390392.

17. Stone KM, Becker TM, Hadgu A, Kraus SJ. Treatment of external genital warts: a randomised clinical trial comparing podophyllin, cryotherapy, and electrodesiccation. Genitourin Med 1990;66:16-19. 